\title{
Effect of Non-surgical Periodontal Treatment on Gingival Crevicular Fluid Interleukin-1beta and Interleukin-37 in Different Periodontal Diseases
}

\section{Farklı Periodontal Hastalıklarda Cerrahisiz Periodontal Tedavinin Diş Eti Oluğu Sıvısı İnterlökin-1beta ve Interlökin-37 Üzerine Etkisi}

\author{
(D) Emine Pirim Görgün${ }^{1}$, (D) Hülya Toker², (D) Ömer Poyraz ${ }^{3}$ \\ ${ }^{1}$ Sivas Cumhuriyet University Faculty of Dentistry, Department of Periodontology, Sivas, Turkey \\ ${ }^{2}$ University of Health Sciences Turkey, Gülhane Faculty of Dentistry, Department of Periodontology, Ankara, Turkey \\ ${ }^{3}$ Sivas Cumhuriyet University Faculty of Medicine, Department of Microbiology, Sivas, Turkey
}

Keywords

Gingival crevicular fluid, interleukin-37, periodontal treatment, periodontitis

Anahtar Kelimeler

Diş eti oluğu sıvısı, interlökin-37, periodontal tedavi, periodontitis

Received/Geliş Tarihi : 31.07 .2020

Accepted/Kabul Tarihi : 03.01.2021

doi:10.4274/meandros.galenos.2021.09821

Address for Correspondence/Yazışma Adresi: Emine Pirim Görgün MD,

Sivas Cumhuriyet University Faculty of Dentistry, Department of Periodontology, Sivas, Turkey

Phone : +90 5052861381

E-mail : eminepirim09@hotmail.com

ORCID ID: orcid.org/0000-0002-8867-1663

(C) Meandros Medical and Dental Journal, Published by Galenos Publishing House.

This is article distributed under the terms of the Creative Commons Attribution NonCommercial 4.0

International Licence (CC BY-NC 4.0).

\begin{abstract}
Objective: Interleukin-37 (IL-37), which is a natural inhibitor of innate immunity, is correlated with chronic inflammation and some autoimmune diseases. Proinflammatory cytokines, for example, interleukin-1beta (IL-1 $\beta$ ), which plays a key part in the periodontium, can induce IL-37. This study aimed to investigate the effect of non-surgical periodontal treatment on gingival crevicular fluid (GCF) IL37 and IL-1 $\beta$ levels in generalized aggressive periodontitis (G-AgP) and generalized chronic periodontitis (GCP).

Materials and Methods: Thirty-five patients with G-AgP, 30 patients with GCP and 30 volunteers with healthy periodontal status (C) were included in this research. Patient groups received scaling and root planning with periodontal hand instrumentations. Clinical periodontal parameters and GCF samples were collected at baseline and at six weeks following SRP. Biomarker levels in GCF were analysed by enzyme-linked immunosorbent assay.

Results: Both periodontitis groups exhibited significant improvement in clinical parameters $(p<0.05)$. GCF IL-37 levels were significantly higher in G-AgP and GCP groups than in the $C$ group at baseline $(p<0.05)$. Following periodontal treatment, GCF IL-37 levels were decreased and comparable in all groups. The GCF IL- $1 \beta$ levels were significantly higher at baseline in the G-AgP group than those in GCP and C groups, and after periodontal therapy, a decrease was detected in GCF IL-1 $\beta$ levels. GCF levels of IL- $1 \beta$ were positively correlated with GCF IL-37 levels.

Conclusion: Clinical improvement was found in both periodontitis groups after periodontal treatment. IL-1 $\beta$ is a key regulator of periodontal inflammation and bone resorption. According to the results of our research, IL-37 may be useful marker of determining the clinical health and disease status of patients with periodontitis. However, further studies are required to determine the mechanism of IL-37 in periodontal inflammation.
\end{abstract}

Öz

Amaç: Doğal bağışıklığın doğal bir inhibitörü olan interlökin-37 (IL-37), kronik enflamasyon ve bazı otoimmün hastalıklarla ilişkilidir. Periodonsiyumda önemli bir rol oynayan IL-1 beta (IL-1 $\beta$ ) gibi pro-enflamatuvar sitokinler, IL-37'yi indükleyebilir. 
$\mathrm{Bu}$ araştırmada, cerrahi olmayan periodontal tedavinin generalize agresif (G-AgP) ve generalize kronik periodontitiste (GCP) diş eti oluğu sıvısı (DOS) IL-37 ve IL-1 $\beta$ düzeyleri üzerine etkilerinin araştırılması amaçlanmıştır.

Gereç ve Yöntemler: Otuz beş G-AgP hastası, $30 \mathrm{GCP}$ hastası ve 30 periodontal olarak sağlıklı gönüllü (C) çalışmaya dahil edildi. Hasta gruplarına periodontal el aletleri ile detertraj ve kök yüzeyi düzleştirmesi uygulandı. Klinik periodontal parametrelerin ve DOS örneklerinin toplanması başlangıçta ve tedaviden 6 hafta sonra gerçekleştirildi. DOS'daki biyobelirteç seviyeleri enzim bağlı immünosorbent deneyi ile analiz edildi.

Bulgular: Her iki periodontitis grubu da klinik parametrelerde anlamlı düzelme gösterdi $(p<0,05)$. Başlangıçta DOS IL-37 düzeylerinin G-AgP ve GCP gruplarında C grubuna göre anlamlı olarak yüksek olduğu belirlendi $(p<0,05)$. Periodontal tedaviyi takiben tüm gruplarda DOS IL-37 düzeyleri düştü ve benzerdi. Başlangıçta DOS IL-1 $\beta$ düzeylerinin G-AgP grubunda GCP ve C gruplarına göre anlamlı olarak daha yüksek olduğu ve ayrıca periodontal tedaviden sonra DOS IL-1 $\beta$ düzeylerinde bir azalma olduğu tespit edildi. DOS IL-1 $\beta^{\prime}$ nın düzeyi, DOS IL-37 düzeyleri ile pozitif korelasyon gösterdi ve ayrıca periodontal tedaviden sonra DOS IL-1 $\beta$ düzeylerinde bir azalma tespit edildi.

Sonuç: Periodontitis gruplarında periodontal tedavi sonrası klinik iyileşme gözlendi. IL-1ß, periodontal enflamasyon ve kemik rezorpsiyonunun önemli bir düzenleyicisidir. Araştırmamızın bulgularına göre, IL-37, periodontitisli hastaların klinik sağlık ve hastalık durumlarını belirlemek için yararlı bir belirteç olabilir. Bununla birlikte, periodontal enflamasyonda IL-37'nin mekanizmasını belirlemek için daha fazla çalışmaya intiyaç vardır.

\section{Introduction}

Periodontal diseases represent inflammatory diseases, which cause the destruction of hard and soft tissues (1). The inflammatory pathway is triggered by dysbiotic microbiota and several other factors, including gender, smoking, and diabetes, which make a contribution to the development and progression of inflammation (2). Besides, factors influencing the immune response, especially the suppression of the host immune system, also take a considerable part in the progress of periodontal diseases (3-5). Since inflammation is a versatile sequence of events, inflammatory and immune responses involve a multifaceted group of protective and damaging reactions that are mainly intervened by a network of chemokines, pro-inflammatory cytokines, anti-inflammatory cytokines, and matrix metalloproteinases, eventually leading to degradation of the periodontium (6). The interactions of these networks determine the course of inflammation either towards the disease or health.

Proinflammatory cytokines, including interleukin1beta (IL-1 $\beta$ ) are very important in initiating and regulating immune responses in the periodontium by stimulating osteoclastic activity and inflammationinduced bone resorption (7). Higher IL-1 $\beta$ levels were also demonstrated at the moderate and deep pocket sites, indicating a positive correlation between the degree of inflammation and IL-1 $\beta$ levels in gingival tissues and gingival crevicular fluid (GCF) (8-13). Decreases in IL-1 $\beta$ levels after periodontal therapy also support this correlation $(8,14)$.
There are also inhibitory pathways to suppress IL-1 $\beta$ and inflammation within the IL-1 family. IL-37, which represents a member of the IL- 1 family (IL1F7), is an anti-inflammatory cytokine and can be induced by pro-inflammatory cytokines including IL-1 $\beta$, tumor necrosis factor-alpha (TNF- $\alpha$ ), and interferon- $\gamma$ (IFN- $\gamma$ ) in dendritic cells and peripheral blood mononuclear cells (PBMCs) (15). IL-37 has been detected in synoviocytes obtained from subjects with rheumatoid arthritis (RA), macrophages obtained from subjects with Mycobacterium avium infection, foam cells obtained from the atheroma plaque, bowel macrophages obtained from subjects with Crohn's disease, keratinocytes obtained from psoriasis lesions, and monocytes obtained from subjects with lupus (16-18). IL-37 functions as an anti-inflammatory cytokine by reducing the release of pro-inflammatory cytokines. The expression of IL-37 was anomalous in autoimmune diseases, including the increased expression of IL-37 in plasma or peripheral PBMCs $(19,20)$. According to our knowledge, there is only few study that presents information on IL-37 in periodontal diseases. Sağlam et al. (21) conducted on subjects having gingivitis and chronic periodontitis (CP) and reported no significant change in levels of cytokines in GCF, saliva, and plasma specimens. GCF IL-37 levels have also been showed positively correlated with IL$1 \beta$ in aggressive periodontitis ( $\mathrm{AgP}$ ) patients (22).

Imbalanced pro- and anti-inflammatory cytokine activities provide suitable conditions for the initiation of chronic inflammation. The decreased levels of IL37 are associated with disease activity in chronic inflammatory and auto-immune diseases. However, 
there is limited data on IL-37 in the pathogenesis and disease activity of periodontitis. Moreover, whether IL-37 and IL-1 $\beta$ are correlated with each other and the impacts of periodontal treatment on IL-37 levels remain unclear in periodontitis. Therefore, the present research aimed to assess whether GCF IL-37 and IL-1 $\beta$ levels were correlated in patients with aggressive and $\mathrm{CP}$ and in comparison with healthy controls and also to reveal the impacts of periodontal therapy on these cytokines levels.

\section{Materials and Methods}

\section{Patient Population}

Patients were enrolled in the current research by collecting the whole mouth clinical periodontal data. This research was designed as a case-control study. The research protocol of this study was confirmed by the Clinical Research Ethics Committee of Cumhuriyet University in accordance with the Declaration of Helsinki (2016-02/05, date: 16.02.2016), and informed consent was acquired from all subjects. The total number of subjects in the current research was 95, consisting of 35 subjects with generalized aggressive periodontitis (G-AgP) (24 females, 11 males), 30 subjects with generalized chronic periodontitis (GCP) (17 females, 13 males), and 30 periodontally healthy controls (19 females, 11 males).

Clinical examinations [gingival index (GI), plaque index (PI), clinical attachment level (CAL), and probing depth (PD)] were performed (23). Panoramic radiographs were taken and assessed to measure interproximal bone loss from the cementoenamel junction of the tooth to the bone crest in order to diagnose G-AgP or GCP or being periodontally healthy. The diagnostic criteria for G-AgP and GCP were determined according to the classification, which was accepted at the World Workshop for Periodontics and the American Academy of Periodontology (1999) (24).

The selected patients had a minimum of 16 teeth with at least one tooth in each posterior sextant with a minimum of 3 natural teeth. The body mass index (BMI) can affect the release of inflammatory cytokines that we choose the patients who were $\mathrm{BMI}$ values between 18.5 and 24.5. Patients over the age of 35 years, having attachment loss equal to or higher than $5 \mathrm{~mm}$ at multiple tooth sites and having more than three sites of PD higher than $6 \mathrm{~mm}$ including more than one tooth distributed in every quadrant were diagnosed with GCP.

Patients having more than eight teeth with the attachment loss equal to or higher than $5 \mathrm{~mm}$ and the PD equal to or higher than $6 \mathrm{~mm}$, and minimum three affected teeth, being not first molars or incisors, were diagnosed with G-AgP.

Patients without the evidence of attachment loss at multiple sites or with the pocket depth equal to or less than $3 \mathrm{~mm}$ were diagnosed as being periodontally healthy and utilized as controls.

According to "Classification of Periodontal and Periimplant Diseases and Conditions 2017", our G-AgP patients can be included in the "Stage 4, Generalized, Grade C" and our GCP patients can be included in the "Stage 3, Generalized, Grade B" group, based on the clinical parameters, the age of onset and the clinical course of the disease (25).

Exclusion criteria were having the receipt of antibiotics or having undergone periodontal therapy 3 months before the research, conservative or prosthetic restorations in the anterior region, periodontal destruction caused by poor restorations, pregnancy and lactation, a history of systemic disease or medication that might influence the periodontal condition, and subjects lacking capacity to consent for themselves. Furthermore, smoking may constitute the main risk factor in periodontal diseases. Therefore, we have excluded smokers from the study.

\section{Clinical Measurement and Periodontal Therapy}

Full-mouth measurements of probing pocket depth (PPD) and CAL were obtained at six points per tooth. The PI was utilized for scoring the presence of supragingival plaque, while the GI was used for scoring gingival inflammation (26). A Williams periodontal probe (Hu-Friedy, Chicago, IL, USA) was utilized to obtain PD and CAL measures. In all subjects, individual acrylic stents were formed using grooves as reference points to measure CAL. A single specialist performed the collection of clinical data and specimens (E.P.G.). The intra-examiner reproducibility of PPD was evaluated, and the intra-examiner reliability was found to be high ( $\geq 98 \%)$. After the baseline measurements were recorded, phase 1 therapy, consisting of oral hygiene instructions, scaling and root planing (SRP), was implemented on patients having periodontitis (27). The SRP procedure was carried out within 10 days by utilizing Gracey curettes (Hu-Friedy, Chicago, 
IL, USA). No antibiotics were prescribed. Recording of the clinical measurements and GCF sampling from the exemplification sites was performed at baseline and six weeks.

\section{Gingival Crevicular Fluid Collection and Analysis}

Before starting to collect GCF samples, the area surrounding the tooth was isolated using cotton rolls, dried, and the removal of the supragingival plaque was performed by means of a sterile curette. The collection of GCF specimens was carried out, and they were pooled from 3 non-adjacent proximal sites with a moderate PPD. The collection of GCF samples was performed using Periopaper ${ }^{\circledR}$ strips, and they were stored at a temperature of $-80{ }^{\circ} \mathrm{C}$ until the analysis was conducted. $300 \mu \mathrm{L}$ of phosphate buffer solution was added to Eppendorf tubes to extract the collected GCF specimens by impregnating Periopaper. The vial was mixed by the vortex mixer for 1 minute to allow the passage of the GCF liquid to the solution. The obtained contents were used for analyzing IL-1 $\beta$ and IL-37. An enzyme-linked immunosorbent assay kits (Boster, Pleasanton, CA and Elabscience, Wuhan, China) were utilized for measuring the IL-1 $\beta$ and IL-37 levels, following the instructions of the manufacturer.

The calculation of GCF cytokine levels was performed from the standard curves, and they were defined as picogram/site for the total amount of cytokine levels. The score of 0 was given to sites having cytokine levels lower than the limits of the detectability of the assay.

\section{Statistical Analysis}

Clinical and biochemical analyses were carried out using SPSS 22 (IBM, Chicago, IL, USA) program. The Kolmogorov-Smirnov test was performed for analyzing the data distribution. Comparisons between the groups were evaluated by the One-Way ANOVA and Unpaired T tests. The Paired T test was conducted for assessing differences between baseline and 6 -week values in the GCP and G-AgP groups. Pearson correlation was done to compare the GCF IL-37 and IL$1 \beta$ levels with a significance set at $p<0.01$. The level of $p<0.05$ was considered to be statistically significant. The calculation of the sample size was performed under a 5\% error considering a required sample size of 30 in every group, with a statistical power of $80 \%$ (28).

\section{Results}

A total of 35 subjects with G-AgP, 30 subjects with $\mathrm{CP}$, and 30 healthy controls took part in the research. Table 1 contains information on the demographic features of the study groups. When the groups were compared with the healthy controls, no statistically significant differences could be determined with regard to gender. The mean age was significantly lower in the G-AgP group than the GCP group ( $p<0.05)$, but the mean age was similar in the G-AgP and control groups.

In accordance with the results of the statistical analysis of clinical parameters, a significant decrease was detected in subjects with G-AgP and GCP in all clinical parameters with significant improvement at 6 weeks $(p<0.05)$ (Table 2$)$. The PI differed statistically significantly between the G-AgP and GCP groups at baseline. However, after periodontal therapy, the PI was found to be similar in both groups.

In accordance with the findings of GCF cytokine statistical analysis (Table 3, Figure 1 ), the GCF IL-1 $\beta$ level was determined to be significantly higher in the G-AgP group in comparison with that in the GCP and

Table 1. Demographic characteristics of the study groups

\begin{tabular}{|c|c|c|c|}
\hline & $\begin{array}{l}\text { G-AgP } \\
(n=35)\end{array}$ & $\begin{array}{l}\text { GCP } \\
(n=30)\end{array}$ & $\begin{array}{l}\text { Healthy controls } \\
(n=30)\end{array}$ \\
\hline \multicolumn{4}{|l|}{ Age (years) } \\
\hline Mean \pm standard deviation & $28.9 \pm 5.8^{¥}$ & $35.2 \pm 5.9^{*}$ & $30.2 \pm 5.7$ \\
\hline Range & $18-39$ & $25-48$ & $22-44$ \\
\hline \multicolumn{4}{|l|}{ Gender } \\
\hline Male n (\%) & $11(31.4)$ & $13(43.3)$ & $11(36.6)$ \\
\hline Female $\mathrm{n}(\%)$ & $24(68.5)$ & $17(56.7)$ & $19(63.4)$ \\
\hline
\end{tabular}


C groups at baseline. In addition, the GCF IL-1 $1 \beta$ level decreased significantly at 6 weeks in the G-AgP group. The GCF IL-1 $\beta$ level was determined to be significantly higher in the GCP group compared to that in the $C$ group at baseline. Following periodontal therapy, the GCF IL-1 $\beta$ level was similar in G-AgP and GCP groups but GCF IL-1 $\beta$ level was significantly higher in G-AgP and GCP groups than control group.

A significantly higher GCF IL-37 level was determined in the G-AgP and GCP groups in comparison with the $\mathrm{C}$ group at baseline, but after periodontal therapy, the GCF IL-37 level decreased significantly in the patient groups $(p<0.05)$.

In the GCP and G-AgP groups, GCF IL-1 $\beta$ and IL-37 levels were positively correlated at baseline $(p<0.05$, $r=0.930 ; p<0.05, r=0.916)$. Moreover, these cytokines were positively correlated after periodontal therapy in the GCP group ( $p<0.05, r=0.918)$.

In the GCP group, a negative relationship was determined between the baseline PI and GCF IL-1 $\beta$ and IL-37 levels after periodontal therapy $(p<0.05, r=-$ $0.565, r=-0.499$, respectively).

\section{Discussion}

In the current research, we evaluated the levels of pro- and anti-inflammatory cytokines, IL- $1 \beta$ and IL37, in GCP and G-AgP patients before and after nonsurgical periodontal treatment. As far as we know, the present research is the first study that reports data on the impacts of non-surgical periodontal treatment on GCF IL-37 and IL-1 $\beta$ levels in both aggressive and CP. Along with the improved clinical parameters, the GCF IL-1 $\beta$ and IL-37 levels were determined to be elevated and positively correlated in both periodontitis subjects and significantly decreased following periodontal therapy.

On comparison of $\mathrm{PI}, \mathrm{GI}, \mathrm{PD}$ and $\mathrm{CAL}$ values amoung the groups, the mean PI, GI, PD and CAL was found to be statistically highly significant between groups. All clinical periodontal parameters were highly in G-AgP and GCP groups. All clinical parameters decreased after periodontal therapy. Moreover, in good agreement, non-surgical periodontal therapy was found to be effective in this study. It resulted in a significant mean

\begin{tabular}{|c|c|c|c|c|}
\hline & & G-AgP & GCP & Healthy controls \\
\hline \multirow{2}{*}{$\mathrm{PI}$} & Baseline & $1.27 \pm 0.7^{\mathrm{c}, \mathrm{b}}$ & $1.5 \pm 0.6^{b, d}$ & \multirow{2}{*}{$0.5 \pm 0.5$} \\
\hline & 6-week & $0.3 \pm 0.4^{\mathrm{a}}$ & $0.5 \pm 0.5^{a}$ & \\
\hline \multirow{2}{*}{ GI } & Baseline & $1.8 \pm 0.5^{b}$ & $1.8 \pm 0.4^{\mathrm{b}}$ & \multirow{2}{*}{$0.06 \pm 0.2$} \\
\hline & 6-week & $0.6 \pm 0.5^{a, b}$ & $0.5 \pm 0.5^{a, b}$ & \\
\hline \multirow{2}{*}{$\mathrm{PD}(\mathrm{mm})$} & Baseline & $5.4 \pm 1.2^{b}$ & $5.6 \pm 1.2^{\mathrm{b}}$ & \multirow{2}{*}{$2.8 \pm 0.3$} \\
\hline & 6-week & $3.2 \pm 0.7^{a, b}$ & $3.3 \pm 0.6^{a, b}$ & \\
\hline \multirow{2}{*}{$\mathrm{CAL}(\mathrm{mm})$} & Baseline & $9.7 \pm 2.2^{\mathrm{b}}$ & $10 \pm 2.1^{b}$ & \\
\hline & 6-week & $8.1 \pm 1.8^{a, b}$ & $8.4 \pm 1.9^{a, b}$ & \\
\hline
\end{tabular}

\begin{tabular}{|c|c|c|c|c|}
\hline & & G-AgP & GCP & Healthy controls \\
\hline \multirow{2}{*}{ IL-1 $\beta$} & Baseline & $298.09 \pm 86.93^{b, c}$ & $152.0 \pm 96.72^{b}$ & \multirow{2}{*}{$92.81 \pm 20.63$} \\
\hline & 6-week & $139.40 \pm 53.64^{\mathrm{a}}$ & $137.68 \pm 73.04$ & \\
\hline \multirow{2}{*}{ IL-37 } & Baseline & $768.85 \pm 129.91^{b}$ & $714.45 \pm 108.76^{b}$ & \multirow{2}{*}{$489.69 \pm 82.45$} \\
\hline & 6-week & $484.77 \pm 139.12^{\mathrm{a}}$ & $531.1 \pm 101.08^{a}$ & \\
\hline
\end{tabular}

${ }^{a} p<0.05$ different from baseline, ${ }^{b} p<0.05$ different from healthy controls, ${ }^{c} p<0.05$ different from generalized chronic periodontitis, GCP: Generalized chronic periodontitis, G-AgP: Generalized aggressive periodontitis, IL: Interlevkin 

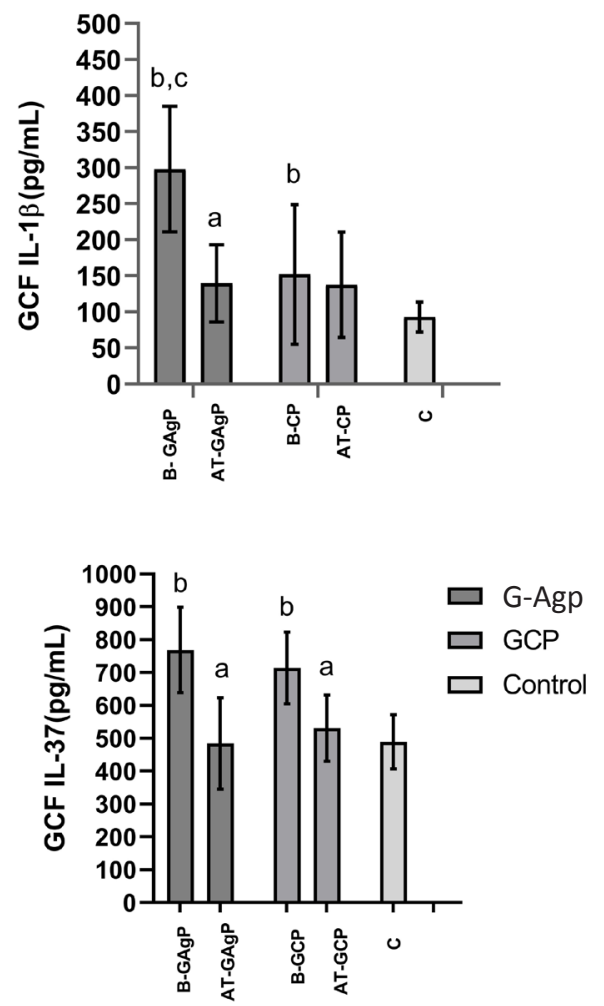

Figure 1. Gingival crevicular fluid (GCF) cytokine levels of the study groups at baseline and after treatment $(\mathrm{pg} / 30 \mathrm{~s}$, mean \pm standard deviation). Mean levels of GCF interleukin- $1 \beta$ and interleukin-37 in the generalized aggressive periodontitis, generalized chronic periodontitis (GCP) and control groups. Significances are shown as marked with different letters $(p<0.05),{ }^{a} p<0.05$ different from baseline; ${ }^{b} p<0.05$ different from healthy controls; ${ }^{c} p<0.05$ different from GCP.

G-AgP: Generalized aggressive periodontitis, GCP: Generalized chronic periodontitis

PPD reduction (G-AgP: $2.2 \mathrm{~mm}, \mathrm{GCP}: 2.3 \mathrm{~mm}$ ) and attachment gain (1.6 $\mathrm{mm}$ in both groups).

In addition to clinical parameters, various laboratory-based diagnostic methods are employed for diagnosing periodontal diseases. The most popular one of these is the GCF content, which is regarded to be of an exudative origin (29). GCF is a fluid that gives significant information about the development of periodontal disease with the components it contains, and at the same time, it is an important step in the host defense mechanism $(30,31)$. In this research, the collection of GCF was performed by paper strips along 30 seconds for the purpose of avoiding serum contamination and cytokine secretion caused by the mechanical irritation stimulated by a longer period of collection. Moreover, we evaluated the total amount of cytokines in GCF samples, because the total amount of cytokines in a GCF sample per sampling time has been indicated as a better marker of relative GCF constituent activity in comparison with the GCF volume which may lead to the reduced cytokine concentration $(32,33)$.

In the present study, in accordance with the results of studies mentioned below, GCF IL-1 $\beta$ level decreased after treatments of G-AgP and GCP patients IL-1 $\beta$ prominently mediates the inflammatory response and takes part in cell proliferation, differentiation, apoptosis, and in the periodontitis pathophysiology. A number of studies indicated an association between GCF IL-1 $\beta$ levels and the inflammatory status of periodontal disease (34). Furthermore, IL-1 $\beta$ and TNF- $\alpha$ effectively induce bone resorption and inhibit bone formation (35). Toker et al. (13) reported that periodontal treatment meaninfully healed the clinical complaints and this positive effects were in accordance with the decreased IL-1 $\beta$ in GCF.

Being a member of the IL-1 family, IL-37 was determined to be the main suppressor of innate immunity and the major regulator of inflammation on mucosal surfaces (18). A negative feedback loop, regulating excessive inflammatory responses, is induced by IL-37. Furthermore, IL-37 represents a new pro-angiogenic cytokine, which effectively stimulates endothelial cell activation and pathological angiogenesis, playing a mediating role in the binding of IL-37 to the TGF- $\beta$ receptor complex (36). It was stated that the elevated IL-37 expression in plasma cells (in normal as well as in pathological tissues) indicates a possible function of IL-37 in the production of immunoglobulin and B-cell activation (37). Furthermore, there has been a correlation between IL-37 and inflammatory and autoimmune diseases, including systemic lupus erythematosus (SLE) and Guillain-Barré syndrome $(19,38)$. Moreover, circulating IL-37 levels were determined to be higher in individuals having systemic inflammatory diseases, e.g. RA (18) and SLE (19), and cardiovascular diseases (39). In an independent sample including 4927 German/Dutch adults, an association was found between IL-37 variants and severe $\mathrm{CP}$, incident tooth loss ( $\geq 3$ teeth) for 10 years, and AgP. Additionally, a decrease was determined in two IL-37 variants having 
functional roles in the expression of IL-37, which caused the up-regulation of IL-1 $\beta$ and IL-6. Decreased IL-37 levels lead to the upregulation of IL-1 $\beta$ and IL- 6 and thus to the increased hyperinflammatory state, which was indicated by Offenbacher et al. (40). They also reported that the IL-37 variants are associated both severe inflammatory response and clinical parameters of the periodontal diseases. Similarly, in the current research, all subjects were systemically healthy, and the GCF IL-37 level was found to be significantly higher in the G-AgP and GCP groups in comparison with the $C$ group at baseline. Unlike our findings, Sağlam et al. (21) suggested a similar total amount of IL-37 in GCF, or salivary or plasma concentrations of IL-37 in gingivitis and CP subjects and healthy controls. In clinical studies, creating a study population with similar disease severity, systemic condition, environmental factors, or stress levels, all of which could influence the overall inflammatory condition of an individual, is a challenging task. Therefore, the difference between the present study and the study by Sağlam et al. (21) might result from the patient selection and the degree of inflammation in their study population.

Cytokines like IL-1 $\beta$ may up-regulate IL-37. We revealed that GCF IL-1 $\beta$ and IL-37 levels were positively associated in the GCP and G-AgP groups at baseline, but these cytokines were positively correlated after periodontal therapy only in the GCP group. Here, it made us think about the rate of decrease in cytokines after treatment, the decrease in the amount of GCF IL-37 in G-AgP was as pronounced as it caught $C$ group. In a disease with an aggressive course, there may be a more significant improvement in the inflammatory process with treatment.

Nevertheless, according to our knowledge, no research has been conducted to compare our results. However, in a study which investigated the alteration in the concentration of IL-37 in RA subjects undergoing disease-modifying anti-rheumatic drug (DMARD) therapy and in which an association was determined between IL-37 and pro-inflammatory cytokines in plasma and disease activity, the researchers detected a positive association between the plasma IL-37 level in RA subjects and pro-inflammatory cytokines, including IL-17A and TNF- $\alpha$, and disease activity (C-reactive protein, DAS28). Additionally, a decrease was observed in the plasma anti-inflammatory cytokine IL-37 level in drug responders following DMARD therapy (41). Furthermore, in another study, IL-37 levels were determined to be significantly lower after glucocorticoid therapy than before treatment in untreated subjects who had been recently diagnosed with lupus (16). In terms of the function of IL-37 in inflammation and inflammation-driven bone resorption, Saeed et al. (42) reported that lipopolysaccharide-induced osteoclast formation and bone resorption were inhibited. Additionally, in a recent study, systemically administrated rhIL-37b was reported to reduce alveolar bone loss via suppressing IL-beta and myeloperoxidase levels in the inflamed gingival tissue in rats (40). The anti-inflammatory impact of IL-37b has also been investigated in vivo and in vitro in different diseases $(43,44)$. According to the research results, anti-IL-37 therapy can be a therapeutic target for treating periodontitis in the future. In a study, Talmac et al. (22) analyzed the correlation between GCF IL-1 $\beta$, IL-37 levels and periodontal parameters in AgP patients after periodontal therapy with different laser therapies. They reported a significant decrease in GCF IL-1 $\beta$, IL37 levels in all groups and they highlighted protective role of IL-37 from excessive inflammatory response in periodontal diseases.

\section{Conclusion}

According to the results of the present research, IL-37 increased with the disease activity, and it might be utilized for monitoring the disease progression in patients having severe periodontal inflammation. In the current research, an association between GCF IL37 levels and disease activity was determined.

As a result of the study, it was found out that the GCF levels of IL-37 and IL-1 $\beta$ were elevated in subjects having G-AgP and GCP and decreased after periodontal treatment, accompanied by improved clinical parameters. IL-37 and IL-1 $\beta$ levels were positively associated in both periodontitis groups. Moreover, these findings indicate a possible role of IL37 in the pathogenesis of periodontitis. However, the detailed molecular mechanism of IL-37 and its relation to the cytokine network in periodontitis should also be proved in future research.

\section{Ethics}

Ethics Committee Approval: The research protocol of this study was confirmed by the Clinical Research 
Ethics Committee of Cumhuriyet University in accordance with the Declaration of Helsinki (201602/05, date: 16.02.2016).

Informed Consent: Informed consent was acquired from all subjects.

Peer-review: Externally peer-reviewed.

\section{Authorship Contributions}

Concept: E.P.G., Design: E.P.G., H.T., Supervision: E.P.G., Fundings: E.P.G., Materials: E.P.G., Data Collection or Processing: E.P.G., H.T., Ö.P., Analysis or Interpretation: Ö.P., Literature Search: E.P.G., Critical Review: E.P.G., H.T., Writing: E.P.G., H.T.

Conflict of Interest: No conflict of interest was declared by the authors.

Financial Disclosure: The Scientific Research Project Fund of Cumhuriyet University provided support for the study under project number Dis-179.

\section{References}

1. Dentino A, Lee S, Mailhot J, Hefti AF. Principles of periodontology. Periodontol 2000. 2013; 61: 16-53.

2. Hasan A, Palmer R. A clinical guide to periodontology: Pathology of periodontal disease. Br Dent J 2014; 216: 457-61.

3. Nędzi-Gora M, Kowalski J, Gorska R. The immune response in periodontal tissues. Arch Immunol Ther Exp (Warsz) 2017; 65: 421-9.

4. Bosshardt DD. The periodontal pocket: pathogenesis, histopathology and consequences. Periodontol 2000. 2018; 76: 43-50.

5. Henderson B, Kaiser F. Bacterial modulators of bone remodeling in the periodontal pocket. Periodontol 2000 2018; 76: 97-108.

6. Zein Elabdeen HR, Mustafa M, Ali R, Bolstad Al. Cytokine profile in gingival crevicular fluid and plasma of patients with aggressive periodontitis. Acta Odontol Scand 2017; 75: 616-22.

7. Gilowski L, Wiench R, Plocica I, Krzeminski TF. Amount of interleukin-1 $\beta$ and interleukin-1 receptor antagonist in periodontitis and healthy patients. Arch Oral Biol 2014; 59: 729-34.

8. Al-Shammari KF, Giannobile WV, Aldredge WA, lacono VJ, Eber $\mathrm{RM}$, Wang $\mathrm{HL}$, et al. Effect of non-surgical periodontal therapy on C-telopeptide pyridinoline cross-links (ICTP) and interleukin-1 levels. J. J Periodontol 2001; 72: 1045-51.

9. Faizuddin $\mathrm{M}$, Bharathi S, Rohini N. Estimation of interleukin-1 $\beta$ levels in the gingival crevicular fluid in health and in inflammatory periodontal disease. J Periodontal Res 2003; 38: 111-4.

10. Hou LT, Liu CM, Rossomando EF. Crevicular interleukin-1 $\beta$ in moderate and severe periodontitis patients and the effect of phase I periodontal treatment. J Clin Periodontol 1995; 22: 162-7.

11. Engebretson SP, Grbic JT, Singer R, Lamster IB. GCF IL-1 $\beta$ profiles in periodontal disease. J Clin Periodontol 2002; 29: 48-53.
12. Reinhardt RA, Stoner JA, Golub LM, Lee HM, Nummikoski PV, Sorsa $\mathrm{T}$, et al. Association of gingival crevicular fluid biomarkers during periodontal maintenance with subsequent progressive periodontitis. J Periodontol 2010; 81: 251-9.

13. Toker $\mathrm{H}$, Poyraz $\mathrm{O}$, Eren $\mathrm{K}$. Effect of periodontal treatment on IL-1 $\beta$, IL-1ra, and IL-10 levels in gingival crevicular fluid in patients with aggressive periodontitis. J Clin Periodontol 2008; 35: 507-13.

14. Rosalem W, Rescala B, Teles R, Fischer R, Gustafsson A, Figueredo C. Effect of non-surgical treatment on chronic and aggressive periodontitis: clinical, immunologic, and microbiologic findings. J Periodontol 2011; 82: 979-89.

15. Wang L, Quan Y, Yue Y, Heng X, Che F. Interleukin-37: A crucial cytokine with multiple roles in disease and potentially clinical therapy. Oncol Lett 2018; 15: 4711-9.

16. Song L, Qiu F, Fan Y, Ding F, Liu H, Shu Q, et al. Glucocorticoid regulates interleukin-37 in systemic lupus erythematosus. J Clin Immunol 2013; 33: 111-7.

17. Boraschi D, Lucchesi D, Hainzl S, Leitner $M$, Maier $E$, Mangelberger $D$, et al. IL-37: a new anti-inflammatory cytokine of the IL-1 family. Eur Cytokine Netw 2011; 22: 127-47.

18. Nold MF, Nold-Petry CA, Zepp JA, Palmer BE, Bufler P, Dinarello CA. IL-37 is a fundamental inhibitor of innate immunity. Nat Immunol 2010; 11: 1014-22.

19. Ye L, Ji L, Wen Z, Zhou Y, Hu D, LiY, et al. IL-37 inhibits the production of inflammatory cytokines in peripheral blood mononuclear cells of patients with systemic lupus erythematosus: its correlation with disease activity. J Transl Med 2014; 12:

20. Xu W-D, Zhao Y, Liu Y. Insights into IL-37, the role in autoimmune diseases. Autoimmun Rev 2015; 14: 1170-5.

21. Sağlam M, Köseoğlu $S$, Savran L, Pekbağriyanik $T$, Sağlam G, Sütçü R. Levels of interleukin-37 in gingival crevicular fluid, saliva, or plasma in periodontal disease. J Periodontal Res 2015; 50: 614-21.

22. Talmac AC, Calisir M, Eroglu EG, Ertugrul AS. Effects of Er, Cr: YSGG and diode lasers on clinical parameters and gingival crevicular fluid IL-1 $\beta$ and IL-37 levels in generalized aggressive periodontitis. Mediators Inflamm 2019; 2019: 2780794.

23. Löe $H$. The gingival index, the plaque index and the retention index systems. J Periodontol 1967; 38: 610-6.

24. Armitage GC. Development of a classification system for periodontal diseases and conditions. Ann Periodontol 1999; 4: 1-6.

25. 25. Caton JG, Armitage G, Berglundh T, Chapple IL, Jepsen S, Kornman KS, et al. A new classification scheme for periodontal and peri-implant diseases and conditions-Introduction and key changes from the 1999 classification. J Periodontol 2018; 89: S1-S8.

26. Loe $H$. The Gingival Index, the Plaque Index and the Retention Index Systems. Periodontol 1967; 38:Suppl: 610-6.

27. Lindhe J, Nyman S, Lang N. Treatment planning. CPID 2003; 3 : 420-37.

28. Özçaka Ö, Nalbantsoy A, Buduneli N. Interleukin-17 and interleukin-18 levels in saliva and plasma of patients with chronic periodontitis. J Periodontal Res 2011; 46: 592-8. 
29. Champagne CM, Buchanan W, Reddy MS, Preisser JS, Beck JD, Offenbacher S. Potential for gingival crevice fluid measures as predictors of risk for periodontal diseases. Periodontol 2000. 2003; 31: 167-80.

30. Page RC. Host response tests for diagnosing periodontal diseases. J Periodontol 1992; 63(4 Suppl): 356-66.

31. Genco RJ. Host responses in periodontal diseases: current concepts. J Periodontol 1992; 63(4 Suppl): 338-55.

32. Figueredo $C$, Ribeiro $M$, Fischer $R$, Gustafsson A. Increased interleukin-1 $\beta$ concentration in gingival crevicular fluid as a characteristic of periodontitis. J Periodontol 1999; 70: 1457-63.

33. Gamonal J, Acevedo A, Bascones A, Jorge O, Silva A. Levels of interleukin-1 $\beta,-8$, and-10 and RANTES in gingival crevicular fluid and cell populations in adult periodontitis patients and the effect of periodontal treatment. J Periodontol 2000; 71: 1535-45.

34. Oh $\mathrm{H}$, Hirano J, Takai $\mathrm{H}$, Ogata Y. Effects of initial periodontal therapy on interleukin- $1 \beta$ level in gingival crevicular fluid and clinical periodontal parameters. J Oral Sci 2015; 57: 67-71.

35. Stashenko P, Dewhirst FE, Rooney ML, Desjardins LA, Heeley JD. Interleukin- $1 \beta$ is a potent inhibitor of bone formation in vitro. J Bone Miner Res 1987; 2: 559-65.

36. Zhao M, Hu Y, Jin J, Yu Y, Zhang S, Cao J, et al. Interleukin 37 promotes angiogenesis through TGF- $\beta$ signaling. Sci Rep 2017; 7: 6113.

37. Kumar $S$, Hanning $C R$, Brigham-Burke $M R$, Rieman DJ, Lehr R, Khandekar S, et al. Interleukin-1F7B (IL-1H4/IL-1F7) is processed by caspase- 1 and mature IL-1F7B binds to the IL-18 receptor but does not induce IFN- $\gamma$ production. Cytokine 2002; 18: 61-71.

38. Li C, Zhao P, Sun X, Che Y, Jiang Y. Elevated levels of cerebrospinal fluid and plasma interleukin-37 in patients with Guillain-Barré syndrome. Mediators Inflamm 2013; 2013: 639712.

39. Ji $Q$, Zeng $Q$, Huang $Y$, Shi $Y$, Lin $Y, L u ~ Z$, et al. Elevated plasma IL-37, IL-18, and IL-18BP concentrations in patients with acute coronary syndrome. Mediators Inflamm 2014; 2014: 165742.

40. Offenbacher S, Jiao Y, Kim SJ, Marchesan J, Moss KL, Jing L, et al. GWAS for Interleukin-1 $\beta$ levels in gingival crevicular fluid identifies IL37 variants in periodontal inflammation. Nat Commun 2018; 9: 3686.

41. Zhao P-W, Jiang W-G, Wang L, Jiang Z-Y, Shan Y-X, Jiang Y-F. Plasma levels of IL-37 and correlation with TNF- $\alpha$, IL-17A, and disease activity during DMARD treatment of rheumatoid arthritis. PLoS One 2014; 9: e95346.

42. Saeed J, Kitaura H, Kimura K, Ishida M, Sugisawa H, Ochi Y, et al. IL-37 inhibits lipopolysaccharide-induced osteoclast formation and bone resorption in vivo. Immunol Lett 2016; 175: 8-15.

43. Zhao M, Hu Y, Shou J, Su SB, Yang J, Yang T. IL-37 impairs host resistance to listeria infection by suppressing macrophage function. Biochem Biophys Res Commun 2017; 485: 563-8.

44. Tsai Y-C, Tsai T-F. Anti-interleukin and interleukin therapies for psoriasis: current evidence and clinical usefulness. Ther Adv Musculoskelet Dis 2017; 9: 277-94. 